\title{
Grazing affects periphytic algal biomass in the periphyton-macrophyte relationship independently of the substrate type and nutrient status
}

\author{
Monika Tarkowska-Kukuryk*, Wojciech Pęczuła, Tomasz Mieczan \\ Department of Hydrobiology and Protection of Ecosystems, University of Life Sciences in Lublin, Dobrzańskiego 37, 20-262 Lublin, \\ Poland
}

\begin{abstract}
The macrophyte-algae relationship has primary importance in affecting the functioning of shallow lake ecosystems. However, how substratum type, grazing, and nutrient status affect the relationship, is still largely unknown. Here, we studied algal assemblages covering either the submerged macrophyte, Ceratophyllum demersum, or artificial plastic plants with similar morphological complexity to answer these questions. Nutrient status was assessed as eu- and hypertrophic conditions in two separate lakes. In contrast to previous studies, the algal community on artificial substrates resembled to those observed on $C$. demersum. Independently of nutrient status (lakes), algae colonised artificial substrates intensively, but the highest algal biomass was observed in the hypertrophic lake. The community of periphytic algae was represented by diatoms, chlorophytes, and cyanobacteria. In the eutrophic lake, rather diatoms were present with high relative abundance, whereas, in the hypertrophic lake, rather cyanobacteria prevailed. Grazing pressure was high in both lakes and in the case of both substrate types, affecting the biomass of periphytic algae significantly. Our results indicate that macroinvertebrate grazing plays a crucial role in affecting periphytic algal biomass, independently of nutrient status and substratum type in shallow lakes.
\end{abstract}

\section{INTRODUCTION}

The macrophyte-algae relationships are of great importance for the functioning of shallow lake ecosystems (Liboriussen and Jeppesen, 2006; dos Santos et al., 2013). Periphytic algae contribute to the total annual production of a lake significantly, especially in shallow lakes with large littoral zones (Müller, 2000; Azim et al., 2005). By trapping organic and mineral matter, periphyton mats exhibit a clarifying effect on the water column (Adey et al., 1993; Doods, 2003). Under highly eutrophic conditions, nutrient competition between periphyton and phytoplankton may reduce phytoplankton biomass indirectly (Hansson, 1988; Rodusky et al., 2001). High periphyton growth can shorten the period with optimum growth conditions for submerged plants due to shading, and therefore,

Corresponding author: monika.kukuryk@up.lublin.pl

Key words: Artificial substrates; Ceratophyllum demersum; periphytic algae; eutrophic and hypertrophic lakes.

Edited by: Andras Abony, Institute of Ecology and Botany, Vácrátót, Hungary.

Received: 4 September 2020

Accepted: 10 January 2020.

This work is licensed under a Creative Commons Attribution NonCommercial 4.0 License (CC BY-NC 4.0).

${ }^{\circ}$ Copyright: the Author(s), 2020

Licensee PAGEPress, Italy

J. Limnol., 2020; 79(2): 124-137

DOI: 10.4081/jlimnol.2020.1941 shorten the clear-water phase (Roberts et al., 2003). Macrophytes are ideal substrates for periphytic algal growth (Fontaine and Nigh, 1983; Kiss et al., 2003; Laugaste and Reunanen, 2005; Kralj et al., 2006). Depending on their diversity and spatial distribution, macrophytes provide extended surface area for colonization and also act as a nutritional source (Cattaneo and Kalff, 1978; Degans and de Meester, 2002; Tarkowska-Kukuryk, 2014). Moreover, they compete for resources with planktic algae (Sand-Jensen and Borum, 1991; Burkholder, 1996), and also release allelopathic compounds potentially as an adaptive strategy (Erhard and Gross, 2006). However, some studies showed that secretion of biologically active substances by the macrophytes may be less important than plant architecture (Cattaneo and Amireault, 1992; Gosselain et al. 2005) or grazing (Balci and Kennedy, 2003; Hansen et al., 2011) in affecting the abundance and composition of periphytic algae. Macrophyte-associated macroinvertebrates impact periphytic algae to a large extent by grazing, and thus, may enhance macrophytes' growth (Jones et al., 2000). As an example, feeding activity of chironomid larvae might reduce the biomass of periphytic algae substantially (Tall et al., 2006; Tarkowska-Kukuryk, 2013). Artificial substrates such as glass, nylon threads, or bamboo shoots have been frequently used to study the biomass and composition of periphytic algae (Lane et al. 2003; Szlauer-Łukaszewska, 2007; Tarkowska-Kukuryk and Mieczan, 2012; dos Santos et al.,2013). Use of artificial substrates improves sampling precision and they were supposed to be equivalent in terms of substrates for periphytic algal growth. However, most of comparative studies showed differences in periphyton abundance (Morin, 1986), taxonomic composition (Townsend and Gell, 2005) and colonization rate 
(Pete et al., 2007) on artificial substrates compared to natural ones. The artificial substrates, however, did not closely resemble the morphological architecture of natural plants. Even if the colonisation time for submerged plants and artificial substrates was rather similar, colonisations varied with architecture and surface area of macrophyte (Cattaneo and Amireault, 1992).

Here, we performed a mesocosm study on the macrophyte-algae relationships in lakes with different trophic status, focusing on the submerged plant species Ceratophyllum demersum $\mathrm{L}$, and its artificial counterpart C. demersum is a non-rooted submerged plant, with finely dissected leaves, presents in lakes with different nutrient statuses, occurs more frequently under eu- and hypertrophic conditions (Penning et al., 2008). Moreover, it dominates vegetation in highly polluted lakes frequently, where it forms free-floating mats (Melzer, 1999). Therefore, we selected two lakes with eu- and hypertrophic nutrient status and with the occurrence of Ceratophyllum demersum for our study.

We hypothesised that: 1) the artificial substrate increases the surface area for algae colonisation, but algal biomass will be higher on natural substrates due to nutrient release; 2) dissolved nutrients affect algal growth and community structure mainly on artificial substrates, where algae utilize nutrients only from the water column; 3) grazing by invertebrates will control the biomass of periphytic algae on both the natural and artificial substrates.

Here, we focused on i) the structure and biomass of periphytic algae on the natural ( $C$. demersum) and artificial substrates; i) the composition and relative abundance of periphytic algae in the gut content of macroinvertebrate grazers; and ii) the role of environmental variables (e.g., nutrient status) in affecting the substrates-algae relationships.

\section{METHODS}

\section{Study sites}

The study was conducted in two shallow lakes situated in PolesieLubelskie (Eastern Poland). Lake Skomielno $\left(51^{\circ} 29^{\prime} \mathrm{N}, 23^{\circ} 0^{\prime} \mathrm{E}\right.$, surface area $75 \mathrm{ha}$, maximum depth 6.5 $\mathrm{m})$ represents a macrophyte-dominated (MD) clear water lake. The emergent vegetation is dominated by Typha angustifolia L. The submerged macrophytes are represented Stratiotes aloides L. and six accompanying species, Myriophyllum spicatum L., Ceratophyllum demersum L., Potamogeton lucens L., Potamogeton acutifolius (Link ex Roem. \& Schult.), Chara aculeolata Kützingand Chara rudis (A.Braun) Leonhardi). The area covered by vegetation exceeds $60 \%$ of the lake surface area. Lake Syczyńskie $\left(51^{\circ} 17^{\prime} \mathrm{N}\right.$ and $23^{\circ} 14^{\prime} \mathrm{E}$, surface area 5.9 ha, maximum depth $2.9 \mathrm{~m}$ ) is a phytoplankton-dominated (PD), hypertrophic, turbid water lake. The emergent vegetation is dominated by Phragmites australis (Cav.) Trin. ex Steud.) and Schoenoplectus lacustris (L.) Palla). The submerged macrophytes are represented by $C$. demersum and Potamogeton pectinatus L. The area covered by submerged vegetation is approximately $20 \%$ of the lake surface area.

\section{Experimental design}

In MD and PD lake, experimental sites covered with Ceratophyllum demersum were selected for our study. Water depth of the sites was $\sim 1 \mathrm{~m}$. For evaluation of the biomass of $C$. demersum ( $\mathrm{g}$ wet weight (WW) $\mathrm{m}^{-2}$ ), the plants were harvested using a Bernatowicz rake (surface area 0.16 $\mathrm{m}^{2}$ ) (Bernatowicz 1960); at each site, three replicates were taken. Biomass of $C$. demersum amounted for $656.5 \mathrm{~g} \mathrm{WW}$ $\mathrm{m}^{-2}$ in MD lake and $488.2 \mathrm{~g} \mathrm{WW} \mathrm{m}^{-2}$ in PD lake. To avoid the fluctuations in the water level, the sheltered parts of the lakes were selected. At the experimental sites, $C$. demersum does not anchored to the bottom, but formed dense mats floating 30-40 cm under the water surface. Plastic plants with similar morphology to $C$. demersum (length $30 \mathrm{~cm}$ ) were placed among $C$. demersum for periphytic algal growth $(\sim 0.4 \mathrm{~m}$ from the water surface). Each artificial plant was fixed with a cord and styrofoam to keep them floating among $C$. demersum. At each experimental site, 15 artificial plants for algae colonisation and 15 plants for the analysis of macroinvertebrates were introduced at the beginning of April, one month before the first sampling.

\section{Estimating the relationship between biomass of $C$. demersum and its surface area}

At each sampling site, stems of $20 \mathrm{C}$. demersum individuals were collected randomly. In the laboratory, plants were washed under tap water to remove detritus and mineral deposits. Subsequently, 10 leaves from each plant were collected randomly (apical, middle and bottom part of stems) for further measurements. The surface area of the leaves was calculated as a cylinder and two conical tips (Fig. 1). All the measurements were carried out under a binocular microscope with a micrometer. All the stems and leaves were then dried at $105^{\circ} \mathrm{C}$ to obtain the dry weight (DW). The relationship between surface area (dependent variable) and biomass (independent variable) was determined by regression analysis using Statistica 10.0 software (Tab. 1); enabling us to relate periphytic algal and grazer communities on natural and artificial substrates.

\section{Water sampling}

Water samples for chemical analysis were taken simultaneously with algae and grazer sampling in triplicates, in each site and month. The water temperature, $\mathrm{pH}$, conductivity, and dissolved oxygen content were measured in situ using the YSI 556 MPS water quality probe. Water transparency was determined by Secchi disk. The 
concentration of ammonium nitrogen $\left(\mathrm{N}-\mathrm{NH}_{4}\right)$ was determined by a method with Nessler reagent, nitrate nitrogen $\left(\mathrm{N}-\mathrm{NO}_{3}\right)$ by a method with sodium salicylate, total phosphorus (TP), and phosphates $\left(\mathrm{P}_{-}-\mathrm{PO}_{4}\right)$ by a method with ammonium heptamolybdate in the spectrophotometric approach (Hermanowicz et al., 1999). Chlorophyll- $a$ was determined by the spectrophotometric method with ethanol extraction (ISO 1992). The concentration of total organic carbon (TOC) and total suspended solids were measured spectrophotometrically using PASTEL UV.

\section{Periphytic algae sampling}

Algal samples were collected at monthly intervals from May to September, 2012. From the natural substrate, the sample was obtained by cutting off a plant fragment (length $30 \mathrm{~cm}$ ) in the water column and placed in a plastic bag. For the analysis, only young $C$. demersum shoots were collected. From the artificial substrate, the whole artificial plant was collected. Each month at each experimental site, 3 replicates of natural substrate and 3 artificial plants were taken. Subsequently, the contents of each bag were transferred to a plastic bottle filled with $300 \mathrm{~mL}$ of filtered lake water $(\mathrm{GF} / \mathrm{C})$. Periphytic algae were separated from the plant samples by shaking the sealed bottle vigorously for $5 \mathrm{~min}$. Next, the suspension was filtered through a $300-\mu \mathrm{m}$ mesh to avoid contamination of small plant fragments or invertebrates. From this sample, 100 $\mathrm{mL}$ of algal sample was fixed with Lugol's solution, and then with 3:1 formaldehyde-glycerin solution. A 2-mL aliquot was taken from the subsample and placed in a 10$\mathrm{mL}$ Utermöhl counting chamber, and then filled with distilled water. After settling, at least 200 algal cells were counted in transects. All cells of colonial algae were counted; each filament of length $100 \mu \mathrm{m}$ was counted as one cell. Counting and identification were performed at $400 \times$ magnification under an inverted microscope. Identification to genus level was based on the key of van den Hoek et al. (1995). The fresh biomass of algae was then expressed as fresh weight assuming the density of $1 \mathrm{~g}$ $\mathrm{cm}^{-3}$, and then in micrograms per square centimetre of plant surface. The relative abundance of algal taxonomic groups was estimated based on fresh weight biomass (Hillebrand et al., 1999).

\section{Grazer sampling}

Macroinvertebrate grazers (chironomid larvae) were sampled simultaneously with algae. At both experimental sites, three replicates from natural and artificial substrata were taken, each month. The larvae were sampled using a cylindrical apparatus with its openings covered by a 250 $\mu \mathrm{m}$ net. Field samples were transported to the laboratory, and then the larvae were removed from macrophytes, preserved in $4 \%$ formaldehyde solution, counted, and identified. To compare chironomid assemblages between the natural and artificial substrata, the density of larvae was calculated per square centimetre of plant surface.

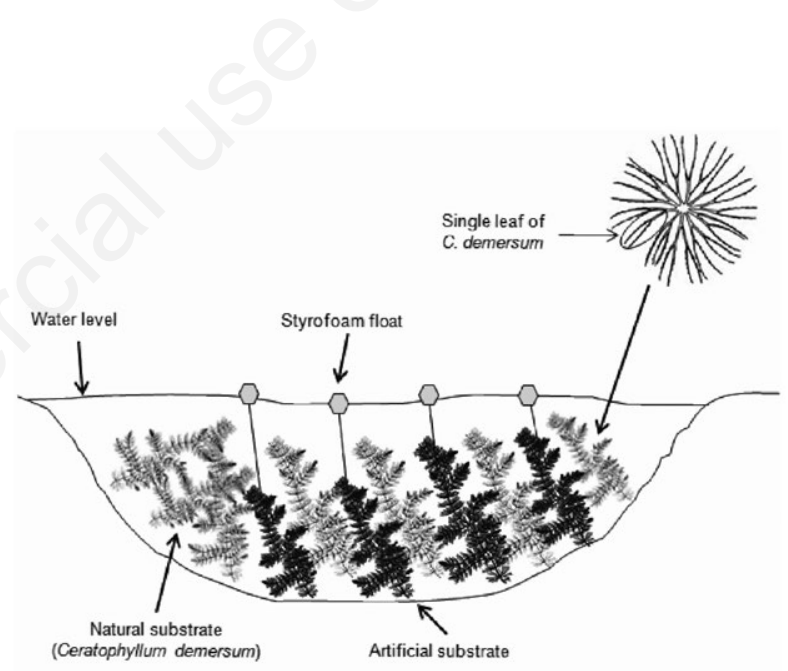

Fig. 1. Transversal view of experimental site with exposition of artificial plants within stands of Ceratophyllum demersum introduced for periphytic algal growth in macrophyte-dominated (MD) and phytoplankton-dominated (PD) lakes.

Tab. 1. Morphological characteristic and relationship between surface area (SA) and biomass (B) of Ceratophyllum demersum leaves and stems in macrophyte-dominated (MD) and phytoplankton-dominated (PD) lakes (mean values $\pm \mathrm{SD}, \mathrm{n}=40$ ).

\begin{tabular}{lcc} 
& MD lake & PD lake \\
Number of plants & 20 & 20 \\
\hline Length of stems $(\mathrm{cm})$ & $39.5( \pm 7.4)$ & $34.2( \pm 12.3)$ \\
\hline Number of leaves per plant & $237( \pm 41)$ & $0.59( \pm 0.18)$ \\
\hline Biomass of single leaf $(\mathrm{mg} \mathrm{DW})$ & $0.33( \pm 0.05)$ & $174( \pm 94)$ \\
\hline Biomass of single stem $(\mathrm{mg} \mathrm{DW})$ & $153( \pm 66)$ & $53( \pm 10)$ \\
\hline Surface area of single leaf $\left(\mathrm{mm}^{2}\right)$ & $41( \pm 6)$ & $6494( \pm 205)$ \\
\hline Surface area of single stem $\left(\mathrm{mm}^{2}\right)$ & $4082( \pm 513)$ & $\mathrm{F}(1.18)=1.71, \mathrm{R}^{2}=0.87, \mathrm{P}=0.020$ \\
\hline Relationship between SA $F(X)$ and B $(X)$ for leaves & $\mathrm{F}(1.18)=1.84, \mathrm{R}^{2}=0.52, \mathrm{P}=0.019$ & $\mathrm{~F}(1.18)=3.73, \mathrm{R}^{2}=0.71, \mathrm{P}=0.039$
\end{tabular}




\section{Gut analysis}

At both experimental sites and on each sampling month, 20 larvae of chironomid grazers were selected for the gut content analysis. The larvae were rinsed to remove any surface debris, decapitated, and dissected along the length of their body, and then placed in Eppendorf tubes filled with filtered water (GF/C filter). The gut contents of single larvae were pooled in one tube. Subsequently, the tubes were fixed on a shaker for $20 \mathrm{~min}$ to dislodge the gut contents from the digestive tube. For identification, the gut content solution was added into a $10 \mathrm{~mL}$ counting chamber, and then filled with filtered lake water (GF/C). After settling, the gut contents were identified, counted, and measured under an inverted microscope equipped with a calibrated micrometer. The relative abundance of cyanobacteria, diatoms, and chlorophytes present in the gut was assessed as the percent ratio of total number of cells (filaments) of each algal group to the total number of particles counted on the slide.

\section{Statistical analyses}

The effect of substratum type, month, and site (lake nutrient status) on the biomass of periphytic algae and density of grazers were evaluated using ANOVA threeway repeated measures. Sampling month was taken as a repeated measure factor; type of substrates and sites as fixe factors. Data was $\log +1$ transformed; and the analyses were performed with Statistica 10.0 software.

Detrended correspondence analysis (DCA) was used to measure the variance gradient of the algal data, and then to perform PCA and RDA. PCA was performed in order to confirm the separation of periphytic algae on natural and artificial substrates within MD and PD lakes. RDA was used to identify the environmental variables affecting the community composition of periphyic algae significantly. Significant variables were retained by Monte Carlo permutation test, at the $\mathrm{P}<0.05$ significance level. The analyses were performed using CANOCO 4.5 software (ter Braak and Šmilauer, 2002).

\section{RESULTS}

\section{Environmental variables}

The physical and chemical parameters showed significant differences between lakes and months. Trophic status of lakes confirmed summer values of Secchi depth ( $1.3 \mathrm{~m}$ in eutrophic lake and $0.4 \mathrm{~m}$ in hypertrophic lake), concentration of TP $\left(0.045 \mathrm{mg} \mathrm{dm}^{-3}\right.$ and $0.301 \mathrm{mg} \mathrm{dm}^{-3}$, respectively), $\mathrm{P}_{-} \mathrm{PO}_{4}\left(0.008 \mathrm{mg} \mathrm{dm}^{-3}\right.$ and $0.028 \mathrm{mg} \mathrm{dm}^{-3}$,

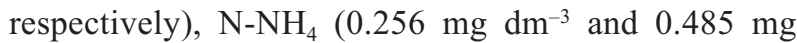
$\mathrm{dm}^{-3}$, respectively) and chlorophyll- $a\left(10.89 \mathrm{mg} \mathrm{dm}^{-3}\right.$ and $31.72 \mathrm{mg} \mathrm{dm}^{-3}$, respectively) (Tab. 2).

\section{Periphytic algae}

Total biomass of periphytic algae was significantly higher in PD lake (RM ANOVA, F=48.27, $\mathrm{P}<0.001$ ). Within the lakes, algal biomass was affected by substrate types significantly (RM ANOVA, $\mathrm{F}=28.42, \mathrm{P}=0.004, \mathrm{MD}$ lake and $\mathrm{F}=26.08, \mathrm{P}=0.006$, $\mathrm{PD}$ lake). Biomass of algae on natural (RM ANOVA, $\mathrm{F}=77.97, \mathrm{P}<0.001$, MD lake and $\mathrm{F}=57.43, \mathrm{P}<0.001$, $\mathrm{PD}$ lake) and artificial $(\mathrm{F}=58.49$, $\mathrm{P}<0.001$, MD lake and $\mathrm{F}=122.2, \mathrm{P}<0.001$, $\mathrm{PD}$ lake) substrata showed significant differences between studied months. Three taxonomic algal groups (chlorophytes, diatoms, and cyanobacteria) were identified on the substrata (Fig. 2, Tab. 3). In the MD lake, on both the natural and artificial substrate, the highest algal biomass was observed in July $\left(123.3 \mu \mathrm{g} \mathrm{cm}^{-2}\right.$ and $65.3 \mu \mathrm{g} \mathrm{cm}{ }^{-2}$, respectively), whereas the lowest values were noted in May $\left(39.4 \mu \mathrm{g} \mathrm{cm}^{-}\right.$

${ }^{2}$ on the natural substratum and $19.8 \mu \mathrm{g} \mathrm{cm}^{-2}$ on the artificial substratum). Diatoms were the dominant group on both substrates. The proportion of this group varied from 39\% (July) to $52 \%$ (September) on the natural substratum and from 36\% (August) to 49\% (May) on the artificial substratum. In the PD lake, the highest biomass of periphytic algae was also observed in July, with $253.6 \mu \mathrm{g} \mathrm{cm}^{-2}$ (natural substratum) and $141.7 \mu \mathrm{g} \mathrm{cm}^{-2}$ (artificial substratum). The lowest values on both the substrata were noted in May, with $60.7 \mu \mathrm{g} \mathrm{cm}^{-2}$ and $46.4 \mu \mathrm{g} \mathrm{cm}^{-2}$, respectively. On both substrate types, cyanobacteria dominated the structure of periphytic algae. The proportion of this group varied from $44 \%$ (August) to 49\% (June) on the natural substrate and from $42 \%$ (June) to $51 \%$ (September) on the artificial substrate.

\section{Grazer community}

Macroinvertebrates on the natural and artificial substrates were represented by chironomid larvae. The density of midges showed significant differences between lakes (RM ANOVA, $\mathrm{F}=234.3, \mathrm{P}<0.001$ ). Within the lakes, density of grazers differed significantly between substrates (RM ANOVA, F=113.8, $\mathrm{P}<0.001$, MD lake and $\mathrm{F}=149.6, \mathrm{P}<0.001$, PD lake). Density of grazers showed seasonal significant variability on natural (RM ANOVA, $\mathrm{F}=66.65, \mathrm{P}<0.001, \mathrm{MD}$ lake and $\mathrm{F}=70.76, \mathrm{P}<0.001, \mathrm{PD}$ lake) and artificial (RM ANOVA, $\mathrm{F}=72.73, \mathrm{P}<0.001, \mathrm{MD}$ lake and $\mathrm{F}=61.55, \mathrm{P}<0.001$, $\mathrm{PD}$ lake) substrata.

In the MD lake, the highest abundance of chironomids on the natural and artificial substrates was observed in September, with 112 ind. $\mathrm{cm}^{-2}$ and 78 ind. $\mathrm{cm}^{-2}$, respectively. In the PD lake, the larvae of midges were the most abundant in May, with 82 ind. $\mathrm{cm}^{-2}$ (natural substratum) and 63 ind. $\mathrm{cm}^{-2}$ (artificial substratum) (Fig. 3).

\section{Periphytic algae in the diet of grazers}

The relative abundance of periphytic algae in the gut content of chironomids showed high temporal variability, 
as well as between, substrate types and lakes. The identified fraction of algae varied between $51 \%$ and $91 \%$ (Fig. 4), the remaining fraction was amorphous detritus. In both the MD and PD lakes, higher relative abundance of algae was observed in the diet of chironomids on the natural substratum (C. demersum). In the MD lake, the larvae fed mostly on diatoms; their percent varied from $34 \%$ to $66 \%$ (natural substratum) and from 29\% to 57\% (artificial substratum) of the larval diet (Fig. 4). In the PD lake, cyanobacteria showed the highest relative abundance in

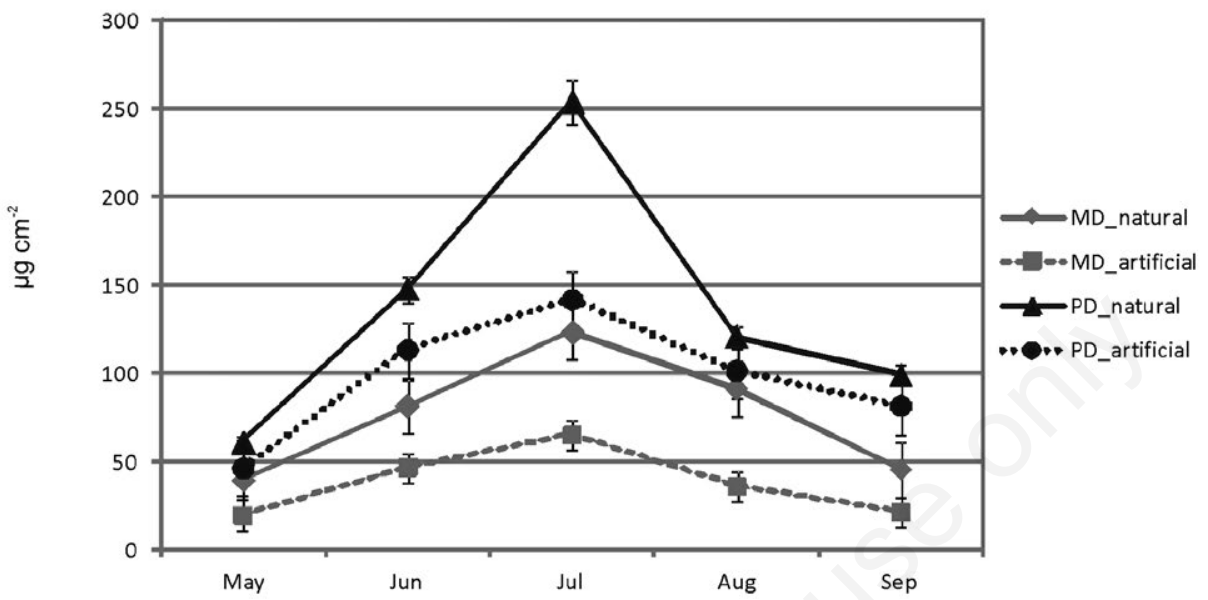

Fig. 2. Mean biomass of periphytic algae $\left(\mu \mathrm{g} \mathrm{cm} \mathrm{cm}^{-2}, \pm \mathrm{SD}, \mathrm{n}=30\right)$ on natural and artificial substrates in macrophyte-dominated (MD) and phytoplankton-dominated (PD) lakes.

Tab. 2. Physical and chemical characteristics of the experimental sites in macrophyte-dominated (MD) and phytoplankton-dominated (PD) lakes (mean values $\pm \mathrm{SD}, \mathrm{n}=30$ ).

\begin{tabular}{|c|c|c|c|c|c|c|c|c|c|c|}
\hline & & & MID lake & & & & & PD lake & & \\
\hline & May & Jun & Jul & Aug & Sep & May & Jun & Jul & Aug & Sep \\
\hline $\begin{array}{l}\text { Temperature } \\
\left({ }^{\circ} \mathrm{C}\right)\end{array}$ & $15.6 \pm 0.9$ & $21.8 \pm 1.3$ & $24.0 \pm 1.4$ & $22.5 \pm 1.3$ & $12.8 \pm 0.8$ & $17.4 \pm 0.9$ & $25.5 \pm 1.3$ & $22.1 \pm 1.1$ & $21.4 \pm 1.2$ & $16.8 \pm 1.0$ \\
\hline $\begin{array}{l}\text { Secchi depth } \\
\text { (m) }\end{array}$ & th $1.5 \pm 0.1^{*}$ & $1.4 \pm 0.08^{*}$ & $1.3 \pm 0.08^{*}$ & $1.3 \pm 0.07^{*}$ & $1.2 \pm 0.07 *$ & $0.7 \pm 0.04$ & $0.8 \pm 0.05$ & $0.4 \pm 0.02$ & $0.3 \pm 0.02$ & $0.4 \pm 0.02$ \\
\hline $\mathrm{pH}$ & $7.5 \pm 0.5$ & $7.7 \pm 0.4$ & $7.8 \pm 0.5$ & $7.7 \pm 0.5$ & $7.6 \pm 0.4$ & $6.9 \pm 0.4$ & $7.3 \pm 0.4$ & $8.3 \pm 0.3$ & $8.4 \pm 0.4$ & $7.7 \pm 0.5$ \\
\hline $\begin{array}{l}\text { Conductivity } \\
\left(\mu \mathrm{S} \mathrm{cm}^{-1}\right)\end{array}$ & ty $331 \pm 19$ & $264 \pm 16$ & $268 \pm 16$ & $253 \pm 15$ & $296 \pm 18$ & $463 \pm 23$ & $394 \pm 24$ & $323 \pm 19$ & $341 \pm 20$ & $437 \pm 26$ \\
\hline $\begin{array}{l}\text { Dissolved } \\
\text { oxygen } \\
\left(\mathrm{mg} \mathrm{L}^{-1}\right)\end{array}$ & $10.8 \pm 0.6$ & $9.7 \pm 0.5$ & $8.8 \pm 0.5$ & $8.9 \pm 0.5$ & $8.3 \pm 0.4$ & $10.9 \pm 0.6$ & $9.2 \pm 0.5$ & $12.4 \pm 0.7$ & $13.2 \pm 0.8$ & $9.1 \pm 0.5$ \\
\hline $\begin{array}{l}\mathrm{TSS} \\
\left(\mathrm{mg} \mathrm{L}^{-1}\right)\end{array}$ & $1.9 \pm 0.2$ & $2.8 \pm 0.2$ & $3.9 \pm 0.2$ & $5.2 \pm 0.3$ & $3.6 \pm 0.2$ & $12.3 \pm 0.7$ & $7.2 \pm 0.4$ & $4.6 \pm 0.3$ & $9.3 \pm 0.6$ & $7.1 \pm 0.4$ \\
\hline $\begin{array}{l}\mathrm{N}-\mathrm{NH}_{4} \\
\left(\mathrm{mg} \mathrm{L}^{-1}\right)\end{array}$ & $0.128 \pm 0.007$ & $0.341 \pm 0.02$ & $0.256 \pm 0.01$ & $0.158 \pm 0.009$ & $0.102 \pm 0.006$ & $0.166 \pm 0.009$ & $0.248 \pm 0.015$ & $0.485 \pm 0.029$ & $0.223 \pm 0.013$ & $0.345 \pm 0.021$ \\
\hline $\begin{array}{l}\mathrm{N}-\mathrm{NO}_{3} \\
\left(\mathrm{mg} \mathrm{L}^{-1}\right)\end{array}$ & $0.098 \pm 0.006$ & $0.036 \pm 0.002$ & $0.080 \pm 0.004$ & $0.054 \pm 0.003$ & $0.023 \pm 0.001$ & $0.036 \pm 0.002$ & $0.090 \pm 0.005$ & $0.045 \pm 0.003$ & $0.057 \pm 0.003$ & $0.166 \pm 0.009$ \\
\hline $\begin{array}{l}\mathrm{P}_{\mathrm{tot}} \\
\left(\mathrm{mg} \mathrm{L}^{-1}\right)\end{array}$ & $0.038 \pm 0.002$ & $0.049 \pm 0.003$ & $0.045 \pm 0.003$ & $0.036 \pm 0.002$ & $0.042 \pm 0.002$ & $0.178 \pm 0.011$ & $0.222 \pm 0.013$ & $0.301 \pm 0.018$ & $0.092 \pm 0.005$ & $0.252 \pm 0.015$ \\
\hline $\begin{array}{l}\mathrm{P}-\mathrm{PO}_{4} \\
\left(\mathrm{mg} \mathrm{L}^{-1}\right)\end{array}$ & $0.007 \pm 0.001$ & $0.009 \pm 0.001$ & $0.008 \pm 0.0004$ & $0.009 \pm 0.0005$ & $0.011 \pm 0.0006$ & $0.047 \pm 0.002$ & $0.173 \pm 0.013$ & $0.028 \pm 0.002$ & $0.036 \pm 0.002$ & $0.186 \pm 0.011$ \\
\hline $\begin{array}{l}\text { TOC } \\
\left(\mathrm{mg} \mathrm{L}^{-1}\right)\end{array}$ & $4.5 \pm 0.3$ & $4.6 \pm 0.3$ & $4.8 \pm 0.2$ & $4.1 \pm 0.2$ & $4.2 \pm 0.3$ & $7.6 \pm 0.5$ & $6.6 \pm 0.3$ & $7.1 \pm 0.4$ & $6.5 \pm 0.4$ & $6.4 \pm 0.3$ \\
\hline $\begin{array}{l}\text { planktonic } \\
\text { chlorophyll- } \\
\left(\mathrm{mg} \mathrm{L}^{-1}\right)\end{array}$ & $\begin{array}{l}7.78 \pm 0.47 \\
-a\end{array}$ & $9.53 \pm 0.57$ & $10.89 \pm 0.65$ & $11.29 \pm 0.67$ & $14.11 \pm 0.84$ & $11.92 \pm 0.71$ & $21.18 \pm 1.2$ & $31.72 \pm 1.9$ & $45.52 \pm 2.7$ & $37.60 \pm 2.3$ \\
\hline
\end{tabular}

\footnotetext{
*to the bottom.
} 
Tab. 3. Composition and mean relative abundances $(\%, \pm \mathrm{SD}, \mathrm{n}=30)$ of periphytic algal taxa on natural (NAT) and artificial (ART) substrates at the experimental sites in macrophyte-dominated (MD) and phytoplankton-dominated (PD) lakes.

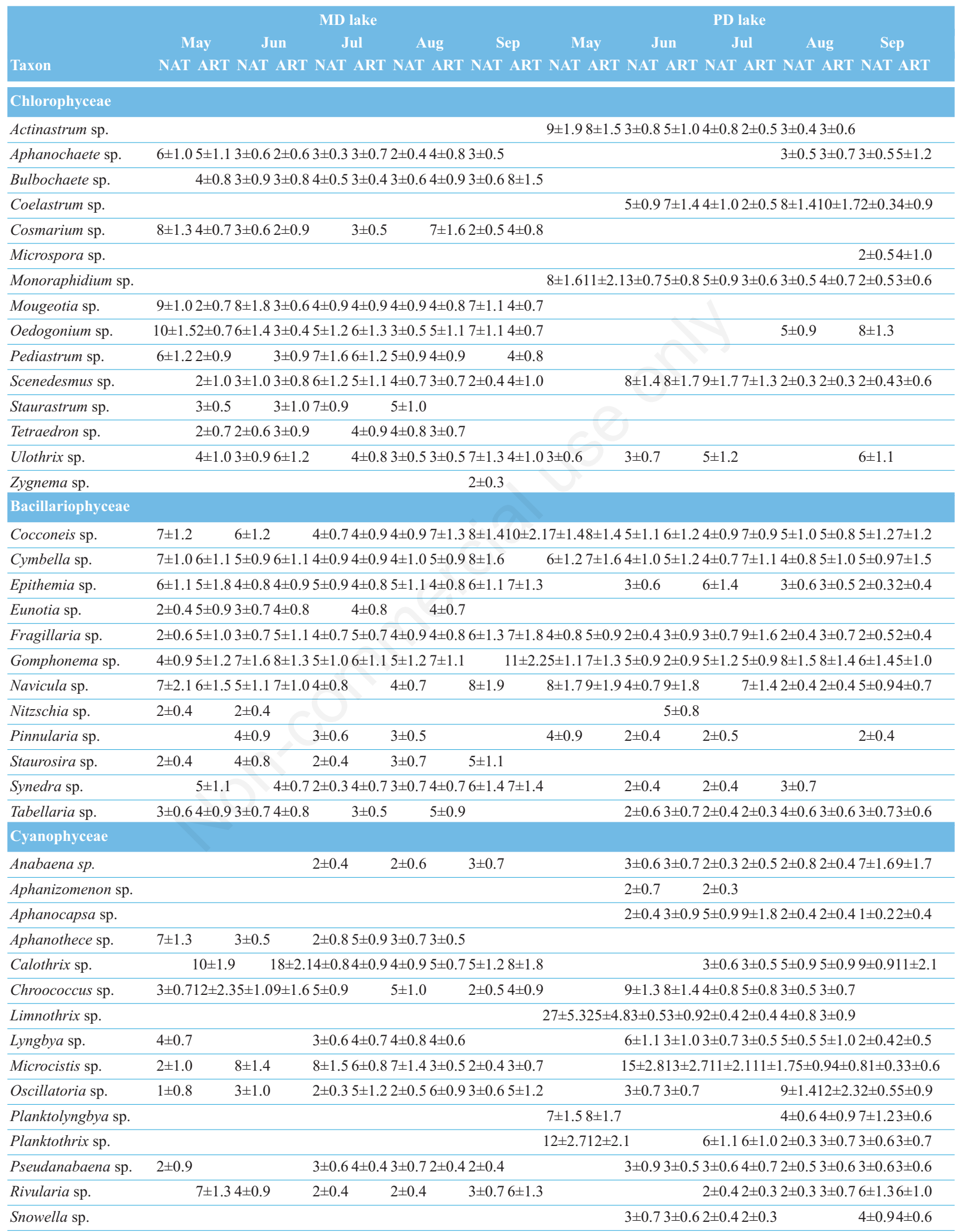


the guts of chironomid grazers during most of the period studied. The percent of larvae varied from $39 \%$ to $62 \%$ on the natural substratum and from $28 \%$ to $47 \%$ on the artificial substratum (Fig. 5). In September, diatoms prevailed in the larval diet, with $75 \%$ (natural substratum) and $62 \%$ (artificial substratum), respectively.

\section{Environmental conditions versus algae structure}

The results of the PCA showed that $68 \%$ of the total variance in algae data is explained by axes 1 and 2. On the ordination plot, axis 1 separated samples collected from the natural and artificial substrates within the lake types. Axis 2 visibly separated the MD and PD lakes (Fig. 5 ). The RDA indicated that the relationships between environmental variables and macrophyte species depended on the type of substrate and lake nutrient status. In the MD lake, the RDA for periphytic algae on the natural substrate showed that all environmental variables accounted for $73 \%$ of the total variance in algal composition, and four variables were significant: chlorophyll- $a$, conductivity, N$\mathrm{NO}_{3}$, total suspension (Tab. 4). On the RDA biplot, filamentous chlorophytes (Ulothrix sp. and Zygnema sp.) and

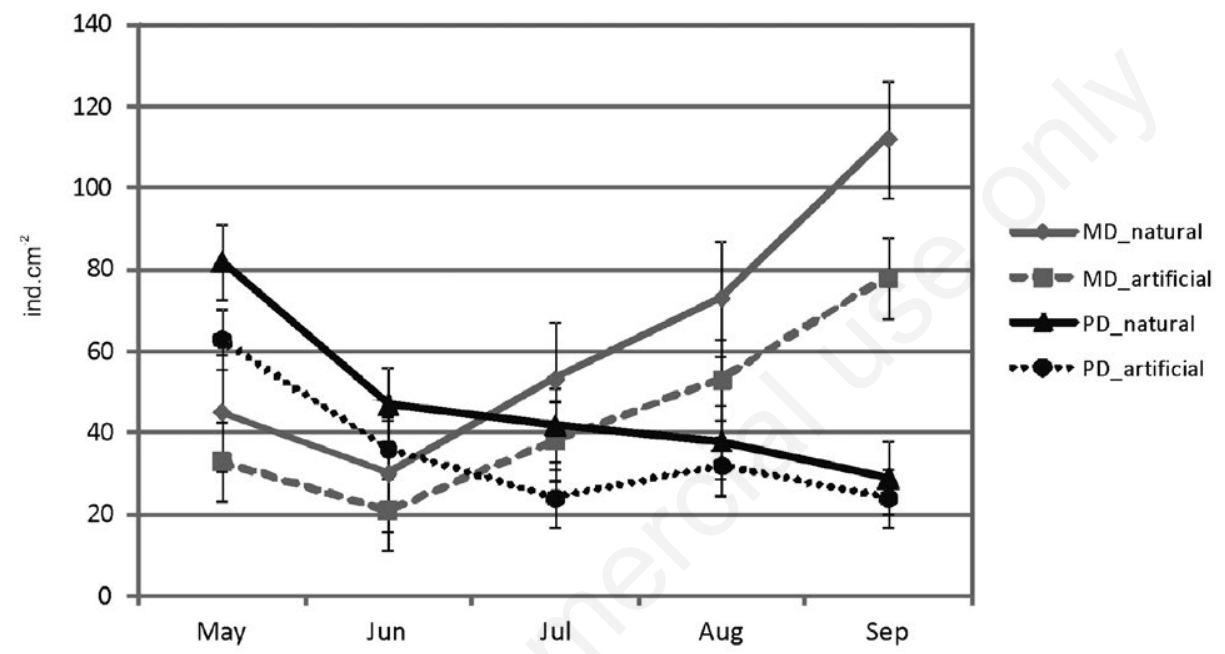

Fig. 3. Mean density (ind. $\mathrm{cm}^{-2}, \pm \mathrm{SD}, \mathrm{n}=30$ ) of grazers associated with natural and artificial substrates in macrophyte-dominated (MD) and phytoplankton-dominated (PD) lakes.

Tab. 4. Significant variables (RDA, Monte Carlo permutation test) determining the community composition of periphytic algae on natural and artificial substrates in macrophyte-dominated (MD) and phytoplankton-dominated (PD) lakes.

\begin{tabular}{|c|c|c|c|c|c|c|}
\hline \multicolumn{7}{|c|}{ MD lake } \\
\hline & \multicolumn{3}{|c|}{ NAT } & \multicolumn{3}{|c|}{ ART } \\
\hline & $\lambda$ & $\mathbf{F}$ & p & $\lambda$ & $\mathbf{F}$ & p \\
\hline Diss. oxy & 0.09 & 11.73 & 0.002 & 0.19 & 8.39 & 0.002 \\
\hline Cond & 0.19 & 12.72 & 0.002 & & & \\
\hline TSS & 0.36 & 7.17 & 0.002 & 0.53 & 14.55 & 0.002 \\
\hline $\mathrm{N}-\mathrm{NO}_{3}$ & 0.28 & 9.46 & 0.002 & 0.04 & 4.37 & 0.002 \\
\hline TOC & 0.01 & 2.64 & 0.016 & 0.13 & 9.01 & 0.002 \\
\hline \multicolumn{7}{|c|}{ PD lake } \\
\hline & \multicolumn{3}{|c|}{ NAT } & \multicolumn{3}{|c|}{ ART } \\
\hline & $\lambda$ & F & p & $\lambda$ & F & p \\
\hline Temp & 0.25 & 8.47 & 0.002 & 0.18 & 10.80 & 0.002 \\
\hline Diss. oxy & 0.09 & 9.39 & 0.002 & & & \\
\hline Cond & & & & 0.08 & 6.79 & 0.002 \\
\hline TSS & & & & 0.24 & 7.54 & 0.002 \\
\hline $\mathrm{TP}$ & 0.17 & 9.96 & 0.002 & & & \\
\hline $\mathrm{P}-\mathrm{PO}_{4}$ & 0.02 & 2.34 & 0.012 & 0.02 & 2.86 & 0.003 \\
\hline Grazers & 0.39 & 8.23 & 0.002 & 0.39 & 8.31 & 0.006 \\
\hline
\end{tabular}


cyanobacteria (Anabaena sp., Aphanocapsa sp., Calothrix sp., and Rivularia sp.) tended to be related to the concentration of chlorophyll- $a$. Conductivity tended to affect the presence of diatoms (Eunotia sp., Nitzschia sp., and Tabellaria sp.) and chlorophytes (Mougeotia sp. and Oedogoniumsp.). A group of diatoms (Cocconeis sp., Cymbella sp., Epithemia sp., Fragilaria sp., Gomphonema sp., Nav- icula sp., and Pinnularia sp.) and chlorophytes (Aphanochaete sp. and Bulbochaete sp.) corresponded with lowering $\mathrm{N}-\mathrm{NO}_{3}$ content. Two chlorophyte taxa, Staurastrum sp. and Scenedesmus sp. tended to be related to the concentration of total suspended solids (Fig. 6A). In the case of the artificial substrates, environmental variables explained $80.6 \%$ of variance in the periphytic algal

\section{MD lake}

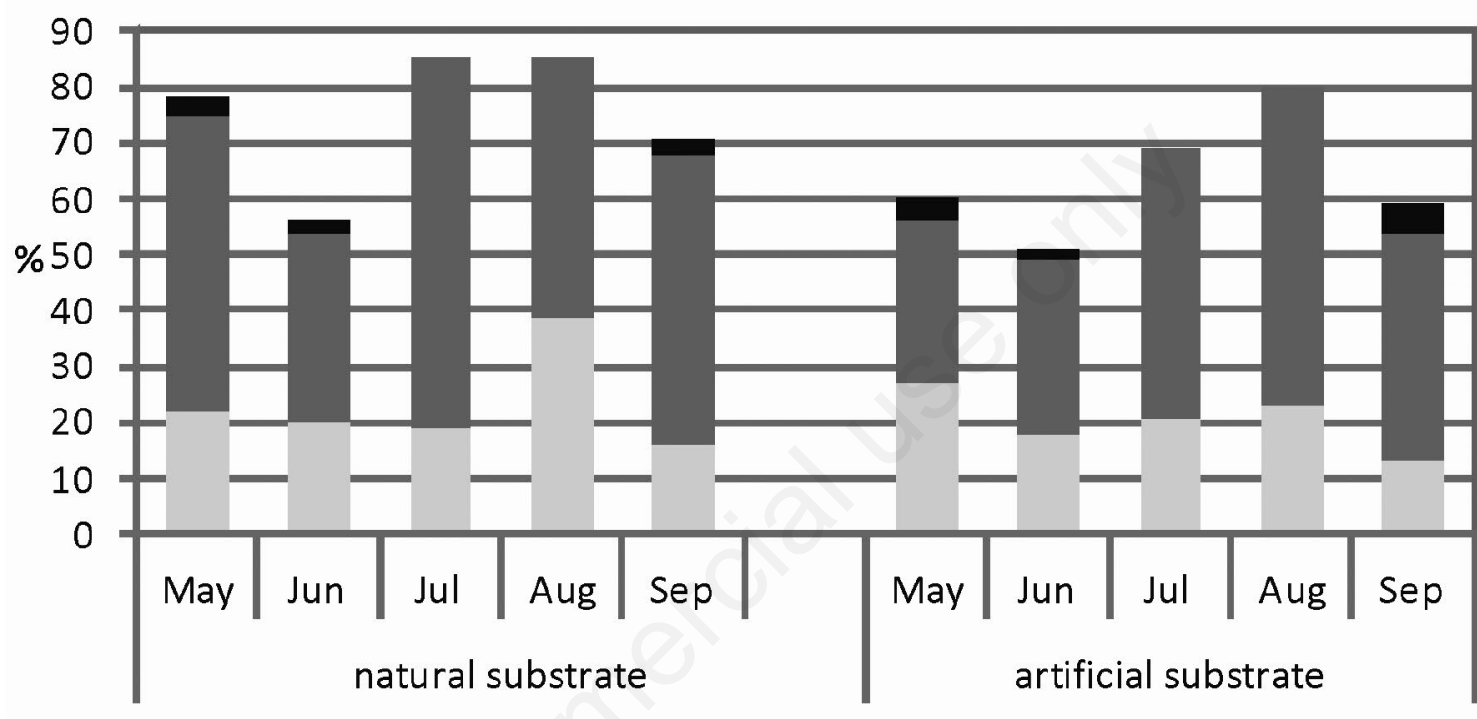

chlorophytes diatoms cyanobacteria

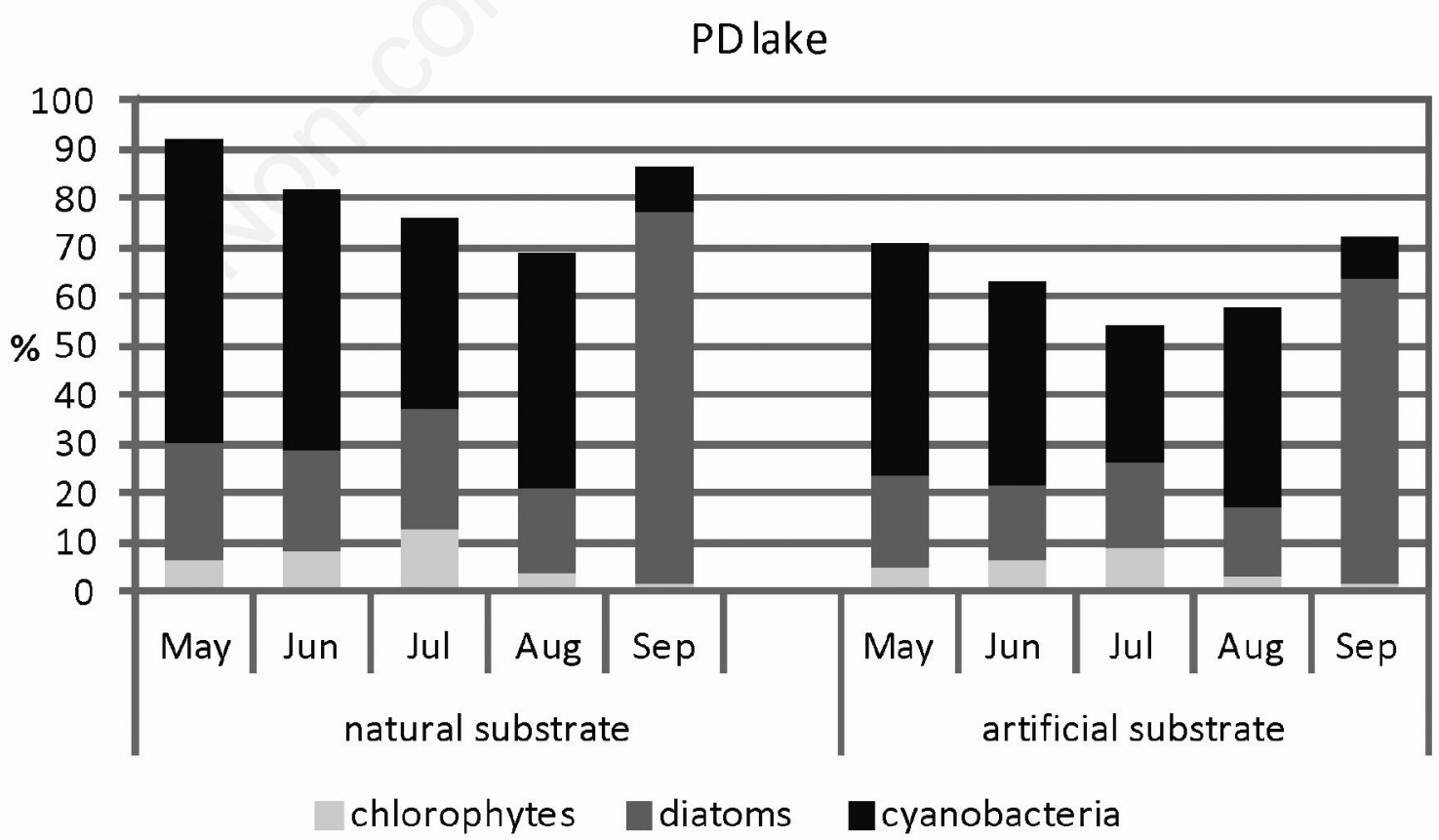

Fig. 4. Relative abundances of periphytic algal groups in the gut contents of chironomid grazers on natural and artificial substrata in macrophyte-dominated (MD) and phytoplankton-dominated (PD) lakes. 
community, with three significant variables: $\mathrm{TOC}, \mathrm{N}-\mathrm{NO}_{3}$ and TSS (Tab. 4). On the RDA biplot, a group of diatoms (Cymbella sp., Epithemia sp., Eunotia sp., Fragillaria sp., Synedra sp., and Tabellaria sp.) and chlorophytes (Aphanochaete sp., Cosmarium sp., and Tetraedronsp.) tended to be related to the concentration of TOC, and N$\mathrm{NO}_{3}$ content. Cyanobacteria (Lyngbyasp., Microcystis sp., Oscillatoria sp., Pseudanabaenasp.) tended to be related to TSS (Fig. 6B).

In the PD lake, on the natural substrate all variables explained $71.2 \%$ of total variance in algae data, and four variables (temperature, TP, $\mathrm{P}_{-} \mathrm{PO}_{4}$ and grazers) were significant (Tab. 4). On the RDA plot, temperature and TP content tended to affect the abundance of chlorophytes (Aphanochaete sp. and Scenedesmus sp.), diatoms (Ep- ithemia sp., Gomphonema sp., and Synedra sp.), and cyanobacteria (Aphanizomenon sp., Chlorococcus sp., and Microcystis sp.). The content of $\mathrm{P}_{-} \mathrm{PO}_{4}$ tended to affect the presence of cyanobacteria (Calothrix sp., Microcystis sp., Oscillatoria sp., and Rivularia sp.) and chlorophytes (Aphanochaete sp. and Oedogonium sp.). A group of diatom taxa (Cocconeis sp., Cymbella sp., Fragillaria sp., and Pinnularia sp.) and chlorophytes (Actinastrum sp., Monoraphidium sp., and Ulothrix sp.) showed a relationship with the grazers (Fig. 7A). On the artificial substrate, the cumulative percent variance in algae data amounted for $71.8 \%$, and six variables showed a significant effect (grazers, TOC, temperature, conductivity, total suspension and $\mathrm{P}_{-} \mathrm{PO}_{4}$ ) on algal community (Tab. 4). On the ordination biplot, the diatom taxa Cocconeis sp., Cymbella sp.,

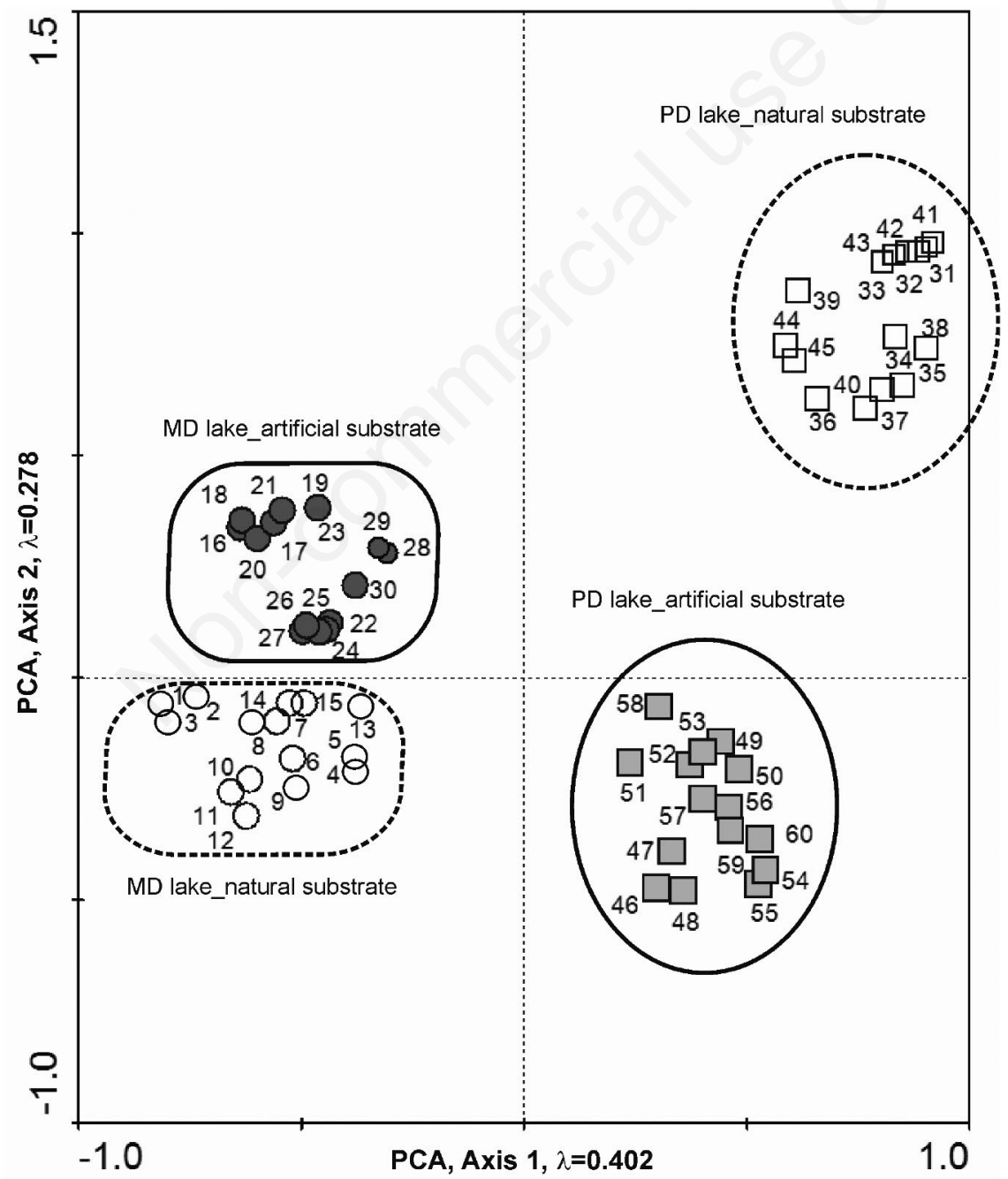

Fig. 5. PCA plot for axis 1 and 2 showing: samples, substratum types and lakes. Samples collected at the studied sites are marked with geometric symbols: white circles - samples collected in macrophyte-dominated (MD) lake on natural substrate; grey circles - samples collected in macrophyte-dominated (MD) lake on artificial substrate; white squares - samples collected in phytoplankton-dominated (PD) lake on natural substrate; grey squares - samples collected in phytoplankton-dominated lake (PD) lake on artificial substrate. 
and Fragillaria sp. showed a relationship with grazers and TOC content. Temperature tended to affect the presence of cyanobacteria (Aphanocapsa sp., Chlorococcus sp., Microcystis sp., and Snowella sp.). Cyanobacteria (Limnothrix sp. and Planktothrix sp.) and diatom taxa Navicula sp. tended to be related to conductivity and TSS. The presence of cyanobacteria (Anabaena sp., Calothrix sp., Microcystissp., Oscillatoria sp., and Rivulariasp.) corresponded with rising $\mathrm{P}_{-} \mathrm{PO}_{4}$ gradient (Fig. 7B).

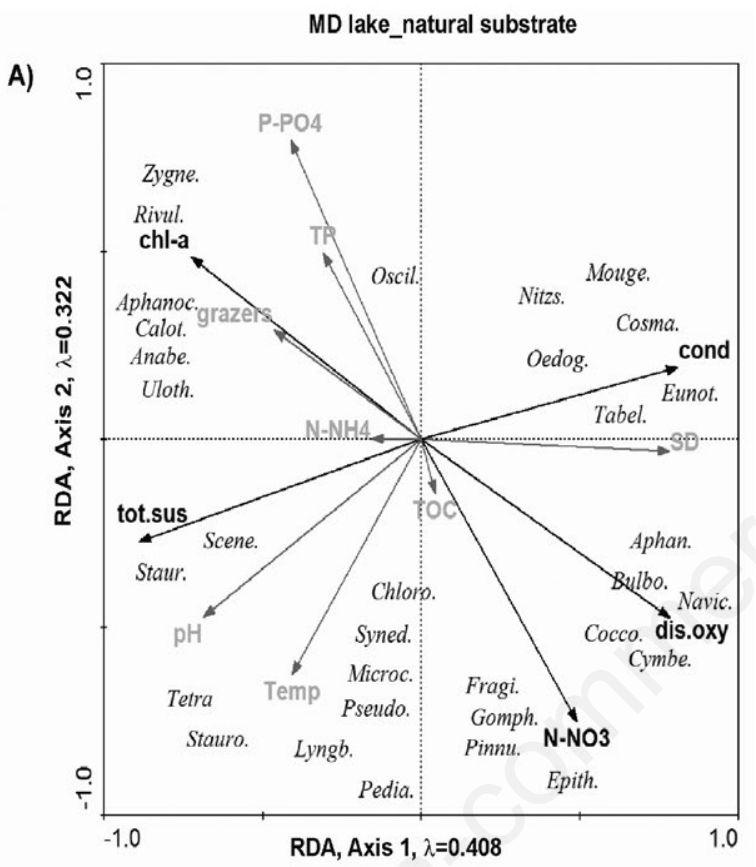

B)

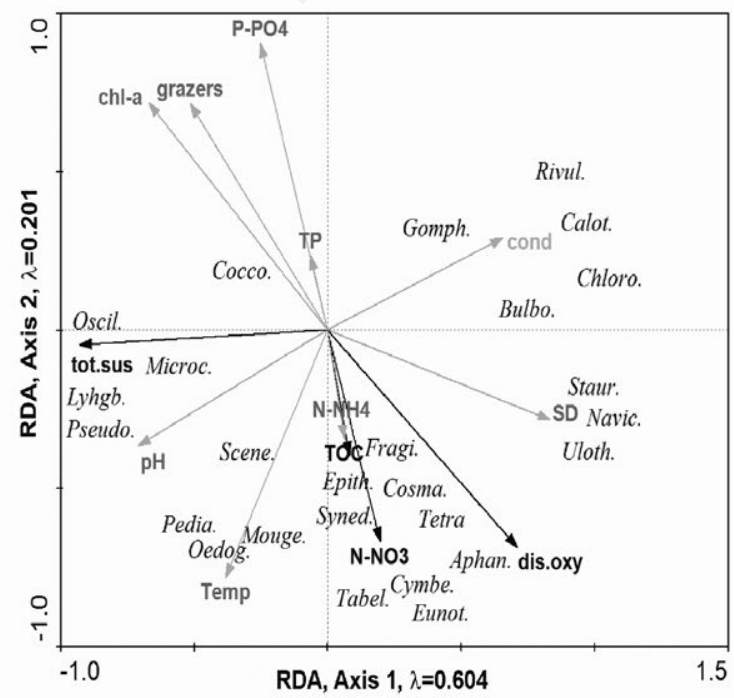

\section{DISCUSSION}

Artificial plants in both lakes were densely colonised by algae, although as it was expected (hypothesis 1), the biomass of algae was lower than on the natural substrata. Similar results were reported by Tarkowska-Kukuryk and Mieczan (2012) in a study on the colonisation process on emergent macrophytes Phragmites australis (Cav.) Trin. ex Steud and bamboo shoots. The observed more intensive growth of periphytic algae on $C$. demersum than on artificial plants is probably the result of the stimulation of algal growth via the secretion of nutrients from macrophytes (Ács et al., 2003). Despite differences in biomass, algae showed similar patterns in the seasonality of biomass and domination structure of algae, both on the natural and artificial substrates. This, might be related to the fact, that our artificial substrate was highly similar in morphological complexity to natural $C$. demersum communities. As it was previously suggested by Tunca et al. (2014) and Hao et al. (2017), complex structure of $C$. demersum allows favourable light conditions for periphytic algal growth, especially when compared to simple-structured plants like Potamogeton lucens. The complex morphological structure of artificial substrates may also increase habitat heterogeneity and provide higher surface area to be colonised (Taniguchi et al., 2003; Pettit et al. 2016). The biomass of periphytic algae on natural and artificial substrates were affected by lake nutrient status (hypothe-

Fig. 6. RDA biplots for macrophyte-dominated (MD) lake showing: A) algae and environmental variables on natural substrata, B) algae and environmental variables on artificial substrata. Solid arrows indicate significant variables based on Monte Carlo permutation test $(p<0.05)$. SD-Secchi depth; Temp-temperature; chl-a-chlorophyll- $a$; cond-conductivity; $\mathrm{N}_{-} \mathrm{NH}_{4}$-ammonium ni-

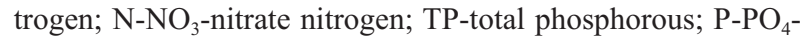
dissolved orthophosphates; TOC-total organic carbon; tot.sus-total suspended solids. Taxa codes:Actin-Actinastrum sp., Aphan-Aphanochaete sp., Bulbo-Bulbochaete sp., CoelaCoelastrum sp., Cosma-Cosmarium sp., Micro-Microspora sp., Monor-Monoraphidium sp., Mouge-Mougeotia sp., Oedog-Oedogonium sp., Pedia-Pediastrum sp., Scene-Scenedesmus sp., Staur-Staurastrum sp., Tetra-Tetraedron sp., Uloth-Ulothrix sp., Zygne-Zygnema sp., Cocco-Cocconeis sp., Cyclo-Cyclotella sp., Cymbe-Cymbella sp., Epith-Epithemia sp., Eunot-Eunotia sp., Fragi-Fragilaria sp., Gomph-Gomphonema sp., Navic-Navicula sp., Nitzs-Nitzschia sp., Pinnu-Pinnularia sp., Staur-Staurosirasp., Surir-Surirella sp., Syned-Synedra sp., Tabel-Tabellaria sp., Anabe-Anabaena sp., Aphaniz-Aphanizomenon sp., Aphanoc-Aphanocapsa sp., Calot-Calothrix sp., Chloro-Chlorococcus sp., Limno-Limnothrix sp., Lyngb-Lyngbya sp., MicrocMicrocystis sp., Oscil-Oscillatoria sp., Planktol-Planktolyngbya sp., Planktoth-Planktothrix sp., Pseudo-Pseudanabaena sp., Rivul-Rivularia sp., Snowe-Snowella sp. 
sis 2). Higher biomass of algae was observed on the natural than on the artificial substrata within the lake types, but in the PD lake, the algal biomass on both substrates was higher than that in the MD lake. This, the most probably, is a direct consequence of high concentration of nutrients in the water column (especially TP), resulting in high periphytic algal biomass. Studies of McCormick et al. (2002) and Gaiser et al. (2006) indicated that periphytic algae accumulate rapidly under eutrophic conditions, thus, increase their biomass in a highly efficient
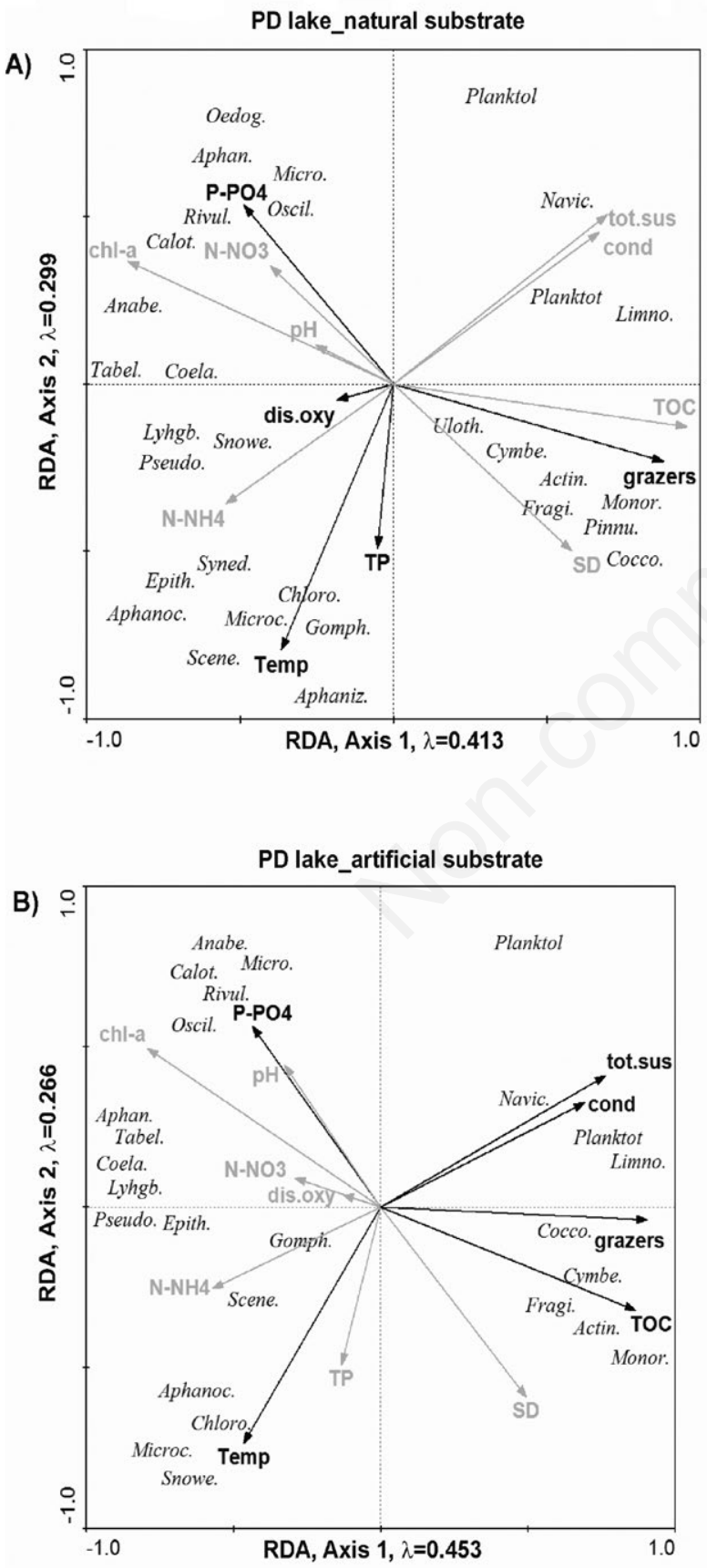

way. In the study, $\mathrm{P}_{-} \mathrm{PO}_{4}$ as a factor favouring the abundance of cyanobacteria (Calothrix sp., Microcystis sp., Oscillatoria sp., and Rivularia sp.) was confirmed by the results of RDA. In MD lake biomass of algae on both substrates were controlled by the concentration of $\mathrm{N}^{-\mathrm{NO}_{3}}$; such tendency was observed on the RDA biplot for the abundance of periphytic diatoms, Cocconeis sp., Cymbella sp., Epithemia sp., Fragillaria sp., Gomphonema sp., Navicula sp., and Pinnularia sp. Stimulation of algal biomass by $\mathrm{N}$ has been previously reported by Bernhardt and Likens (2004), who studied the mechanisms controlling periphyton biomass on artificial substrates and attributed it to competition for $\mathrm{N}$ between algae and other heterotrophic components of the biofilm, e.g., microbes and ciliates. The biomass of periphytic algae on artificial substrates in both lakes was also affected by TOC content. This might suggest that organic matter settled from the water column on artificial substrates enables the attachment of periphytic taxa. The role of organic matter during algal colonisation was previously suggested by Hameed (2003), who studied the colonisation of periphytic diatoms on cylindrical glass beads. In our study, the artificial substrates were introduced one month before the first sampling, which might have enabled the settlement of organic matter on substrates and allow algal colonisation. Within MD and PD lake, biomass of periphytic algae varied with time, being the highest in July and the lowest in May. Such high variation in algae biomass may result from the seasonal variation in the availability of nutrients

Fig. 7. RDA biplots for phytoplankton-dominated (PD) lake showing: A) algae and environmental variables on natural substrata, B) algae and environmental variables on artificial substrata. Solid arrows indicate significant variables based on Monte Carlo permutation test $(\mathrm{P}<0.05)$. SD-Secchi depth; Temp-temperature; chl-a-chlorophyll- $a$; cond-conductivity; $\mathrm{N}_{-} \mathrm{NH}_{4}$-ammonium nitrogen; $\mathrm{N}_{-} \mathrm{NO}_{3}$-nitrate nitrogen; TP-total phosphorous; $\mathrm{P}_{-} \mathrm{PO}_{4}$-dissolved orthophosphates; TOC-total organic carbon; tot.sus-total suspended solids. Taxa codes: Actin-Actinastrum sp., AphanAphanochaete sp., Bulbo-Bulbochaete sp., Coela-Coelastrum sp., Cosma-Cosmarium sp., Micro-Microspora sp., Monor-Monoraphidium sp., Mouge-Mougeotia sp., Oedog-Oedogonium sp., Pedia-Pediastrum sp., Scene-Scenedesmus sp., Staur-Staurastrum sp., Tetra-Tetraedron sp., Uloth-Ulothrix sp., Zygne-Zygnema sp., Cocco-Cocconeis sp., Cyclo-Cyclotella sp., Cymbe-Cymbella sp., Epith-Epithemia sp., Eunot-Eunotia sp., Fragi-Fragilaria sp., Gomph-Gomphonema sp., Navic-Navicula sp., Nitzs-Nitzschia sp., Pinnu-Pinnularia sp., Staur-Staurosirasp., Surir-Surirella sp., Syned-Synedra sp., Tabel-Tabellaria sp., Anabe-Anabaena sp., Aphaniz-Aphanizomenon sp., Aphanoc-Aphanocapsa sp., CalotCalothrix sp., Chloro-Chlorococcus sp., Limno-Limnothrix sp., Lyngb-Lyngbya sp., Microc-Microcystis sp., Oscil-Oscillatoria sp., Planktol-Planktolyngbya sp., Planktoth-Planktothrix sp., PseudoPseudanabaena sp., Rivul-Rivularia sp., Snowe-Snowella sp. 
and grazing pressure (Laugaste and Reunanen, 2005; Toporowska et al., 2008). Dominance structure of periphytic algae was also affected by lake nutrient status. In MD lake diatoms dominated both substrate types; which algae usually show high abundance in lakes densely populated by submerged vegetation (Gross et al., 2003). In the PD lake, rather cyanobacteria dominance was characteristic, both on the natural and artificial substrates. These algae are rather characteristic under highly eutrophic conditions, especially indicate phosphorus enrichment (McCormick and O'Dell, 1996; Gasser et al., 2005). In the hypertrophic lake, as a further possible mechanism, significant portion of cyanobacteria might have settled from the water column.

Moreover, macroinvertebrate grazing affected the biomass of periphytic algae strongly on both substrates (hypothesis 3). As it was assumed, this relationship was more pronounced in PD lake, where the relative abundance of algae in the gut of chironomids accounted for $90 \%$ of the diet. During most of the studied months, diatoms accounted for more than $20 \%$ of the diet of grazers, and during September their proportion was $75 \%$ on natural and $62 \%$ on artificial substrata. As reported by other studies (Pinder, 1992; Tall et al., 2006) diatoms are a basic component of the chironomid diet. High grazing pressure on algae on artificial substrata confirm that in case of significant algal growth, e.g. due to high morphologically complexity of the artificial substrate, grazers do not differentiate between natural and artificial substrates on which periphytic algae may grow.

\section{CONCLUSIONS}

The introduction of artificial plants with similar morphological complexity to $C$. demersum provided an alternative and valuable colonisation area for periphytic algae in our case. The relationship between periphytic algae and host plants (either natural or artificial) within a lake was regulated by similar mechanisms, including the same set of environmental variables, and grazing. Accordingly, macroinvertebrate grazing should be considered as one of the most significant effects in structuring the biomass and community composition of periphytic algae. This finding may contribute to our understanding about the organisation of periphytic algal assemblages; on top of other biotic and abiotic environmental conditions.

\section{ACKNOWLEDGMENTS}

The study was supported by the Polish National Science Foundation under Grant N N304 339133 "Trophic interactions between macrophytes, periphytic algae, epiphytic invertebrates in shallow lake ecosystems". We would like to thank two anonymous reviewers for many valuable critical comments to the manuscript.

\section{REFERENCES}

Ács E, Borsodi AK, Makk J, Molnar P, Mozes A, Rusznyak A, Reskone MN,Kiss KT.2003. Algological and bacteriological investigations on reed periphyton in Lake Velencei, Hungary. Hydrobiologia 506-509:549-557.

Adey W, Luckett C, Jensen K.1993. Phosphorous removal from natural waters using controlled algal production. Restor. Ecol. 1:29-39.

Azim ME, Beveridge MCM, van Dam AA, Verdegem MCJ, 2005. Periphyton and aquatic production: an introduction, p. 2-13 In: M. A. Azim MA et al. (eds.), Periphyton. Ecology, exploitation and management. CABI Publ.

Balci P, Kennedy JH. 2003. Comparison of chironomids and other macroinvertebrates associated with Myriophyllum spicatum and Heteranthera dubia. J. Freshwater Ecol. 18:235-247.

Bernatowicz S. 1960. Methods of plants studies in lakes. Rocz. Nauk. Rol. 77:61-79.

Bernhardt ES, Likens GE.2004. Controls on periphyton biomass in heterotrophic streams. Freshwater Biol. 49:14-27.

Burkholder JM. 1996. Interactions of benthic algae with their substrata, p. 253-297. In: R.J. Stevenson, M. Bothwell and R. Lowe (eds.), Algal ecology: benthic algae in freshwater ecosystems. Academic Press.

Cattaneo A, Kalff J. 1978. Seasonal changes in the epiphyte community of natural and artificial macrophytes in Lake Memphremagog (Que. \&Vt.). Hydrobiologia 60:135-144.

Cattaneo A, Amireault MC. 1992. How artificial are artificial substrata for periphyton? J. N. Am. Benthol. Soc. 11:244-256.

Degans H, De Meester L.2002. Top-down control of natural phyto- and bacterioplankton prey communities by Daphnia magna and by the natural zooplankton community of the hypertrophic Lake Blankaart. Hydrobiologia 479:39-49.

Doods WK. 2003. The role of periphyton in phosphorus retention in shallow freshwater aquatic systems. J. Phycol. 39:840-849.

dos Santos TR, Ferragut C, de Mattos Bicudo CE.2013.Does macrophyte architecture influence periphyton? Relationships among Utricularia foliosa, periphyton assemblage structure and its nutrient $(\mathrm{C}, \mathrm{N}, \mathrm{P})$ status. Hydrobiologia 714:71-83.

Erhard D, Gross EM, 2006. Allelopathic activity of Elodea canadensis and E. nuttallii against epiphytes and phytoplankton. Aquat. Bot. 85:203-211.

Fontaine TD, Nigh DG. 1983. Characteristics of epiphytes communities on natural and artificial submersed lotic plants: substrate effects. Arch. Hydrobiol. 96:293-301.

Gaiser EE, Texler JC, Richards JH, Childers DL, Lee D, Edwards AL, Scinto LJ, Jayachandaran K, Noe GB, Jones RD, 2005. Cascading ecological effects of low-level phosphorous enrichment in the Florida Everglades. J. Environ. Qual. 34:717-723.

Gaiser EE, Childers DL, Jones RD, Richards JH, Scinto LJ, Texler JC, 2006. Periphyton responses to eutrophication in the Florida Everglades: cross-system patterns of structural 
and compositional change. Limnol. Oceanogr. 51:617-630.

Gosselain V, Hudon C, Cattaneo A, Gagnon P, 2005. Physical variables driving epiphytic algal biomass in a dense macrophyte bed of the St. Lawrence River (Quebec, Canada). Hydrobiologia 534:11-22.

Gross EM, Feldbaum C, Graf A, 2003. Epiphyte biomass and elemental composition on submersed macrophytes in shallow eutrophic lakes. Hydrobiologia 506/509:559-65.

Hameed HA, 2003. The colonization of periphytic diatom species on artificial substrates in the Ashar canal, Basrah, Iraq. Limnologica 33:54-61.

Hansen JP, Wikström SA, Axemar H, Kautsky L,2011. Distribution differences and active habitat choices of invertebrates between macrophytes of different morphological complexity. Aquat. Ecol. 45:11-22.

Hansson LA, 1988. Effects of competitive interactions on the biomass development of planktonic and periphytic algae in lakes. Limnol. Oceanogr. 33:121-128.

Hao B, Wu H, Cao Y, Xing W, Jeppesen E, Li W, 2017. Comparison of periphyton communities on natural and artificial macrophytes with contrasting morphological structures. Freshwater Biol. 62:1783-1793.

Hermanowicz W, Dojlido J, Dożańska W, Koziorowski B, Zerbe J, 1999. [Fizyczno-chemiczne badanie wody i ścieków].[Book in Polish]. Arkady, Warszawa.

Hillebrand H, DürselenCD, Kirschtel D, Pollingher U, Zohary T, 1999. Biovolume calculation for pelagic and benthic microalgae. J. Phycol. 35: 403.424.

ISO 10260, 1992. Water quality. Measurement of biochemical parameters. Spectrometric determination of the chlorophylla concentration. PKN, Warszawa.

Jones JI, Moss B, Eaton JW, Young JO.2000. Do submerged aquatic plants influence periphyton community composition for the benefit of invertebrate mutualists? Freshwater Biol. 43:591-604.

Kiss MK, Lakatos G, Borcis G, Gido Z, Deak C, 2003. Littoral macrophyte-periphyton complexes in two Hungarian shallow waters. Hydrobiologia 506-509: 541-548.

Kralj K, Plenkovic-Moraj A, Gligora M, Primc-Habdija B, Sipos L, 2006. Structure of periphytic community on artificial substrata: influence of depth, slide orientation and colonization time in karstic Lake Visovacko, Croatia. Hydrobiologia 560:249-258.

Lane ChM, Taffs KH, Corfield JL, 2003.A comparison of diatom community structure on natural and artificial substrata. Hydrobiologia 493:65-79.

Laugaste R, Reunanen M, 2005. The composition and density of epiphyton on some macrophyte species in the partly meromictic Lake Verevi. Hydrobiologia 547:137-150.

Liboriussen L, Jeppesen E, 2006. Structure, biomass, production and depth distribution of periphyton on artificial substratum in shallow lakes with contrasting nutrient concentrations. Freshwater Biol. 51:95-109.

McCormick PV, O`Dell MB.1996. Quantifying periphyton responses to phosphorous enrichment in the Florida Everglades: a synoptic-experimental approach. J. N. Am. Benthol. Soc. 15:450-468.

McCormick PV, Newman S, Miao S, Gawlik DE, Marley D, Reddy KR, Fontaine TD. 2002. Effects of anthropogenic phosphorous inputs on the Everglades, p. 83-126. In: JW
Porter and KG Porter (eds.), The Everglades, Florida Bay and coral reefs of the Florida Keys: An ecosystem sourcebook. Boca Raton.

Melzer A, 1999. Aquatic macrophytes as tools for lake management. Hydrobiologia 395/396:181-190.

Morin JON, 1986. Initial colonization of periphyton on natural anartificial apices of Myriophyllum heterophyllum Michx. Freshwater Biol. 16: 685-694.

Müller U, 2000. Periphytic primary production during spring. A sink or source of oxygen in the littoral zone? Limnologica 30:169-174.

Penning WE, Mjelde M, Dudley B, Hellsten S, Hanganu J, Kolada A, van den Berg M, Poikane S, Phillips G, Willby N, Ecke F, 2008. Classifying aquatic macrophytes as indicators of eutrophication in European lakes. Aquat. Ecol. 42:237-251.

Pete D, Gobert S, Lepoint G, Poulicek M, Bouquegneau JM, 2007. Early colonization of Posidonia oceanica (L.) Delile byepiphytes: Comparison between natural and artificial seagrass leaves, p. 151-157. Proceedings Third Mediterranean Symposium on Marine Vegetation, Marseilles.

Pettit N, Ward D, Adame M, Valdez D, Bunn S, 2016. Influence of aquatic plant architecture on epiphyte biomass on a tropical river floodplain. Aquat. Bot. 29:35-43.

Pinder LCV, 1992. Biology of epiphytic Chironomidae (Diptera: Nematocera) in chalk stream. Hydrobiologia 248:39-51.

Roberts E, Kroker J, Körner S, Nicklisch A, 2003. The role of periphyton during the re-colonization of a shallow lake with submerged macrophytes. Hydrobiologia 506:525-530.

Rodusky AJ, Steinman AD, East TL, Sharfstein B, Meeker RH, 2001. Periphyton nutrient limitation and other potential growth-controlling factors in Lake Okeechobee, USA. Hydrobiologia 448: 27-39.

Sand-Jensen K, Borum J, 1991. Interactions among phytoplankton, periphyton, and macrophytes in temperate freshwaters and estuaries. Aquat. Bot. 41:137-175.

Szlauer-Łukaszewska A, 2007. Succession of periphyton developing on artificial substrate immersed in polysaprobic wastewater reservoir. Pol. J. Environ. Stud. 16:753-762.

Tall L, Cattaneo A, Cloutier L, Dray S, Legendre P, 2006. Resource partitioning in a grazer guild feeding on a multilayer diatom mat. J. N. Am. Benthol. Soc. 25:800-810.

Taniguchi H, Nakano S, Tokeshi M, 2003. Influences of habitat complexity on the diversity and abundance of epiphytic invertebrates on plants. Freshwater Biol. 48:718-728.

Tarkowska-Kukuryk M, 2013. Periphytic algae as food source for grazing chironomids in a shallow phytoplankton dominated lake. Limnologica 43:254-264.

Tarkowska-Kukuryk M, 2014. Spatial distribution of epiphytic chironomid larvae in a shallow macrophyte-dominated lake: effect of macrophyte species and food resources. Limnology 15:141-153.

Tarkowska-Kukuryk M, Mieczan T, 2012. Effect of substrate on periphyton communities and their relationships among food web components in a shallow hypertrophic lake. J. Limnol. 71:279-290. doi: 10.4081/jlimnol.2012.e30.

TerBraak CJF, Šmilauer P. 2002. CANOCO Reference Manual and User's Guide to Canoco for Windows: Software for Canonical Community Ordination (version 4.5). Microcomputer Power (Ithaca, NY, USA). 
Toporowska M, Pawlik-Skowrońska B, Wojtal AZ, 2008. Epiphytic algae on Stratiotesaloides L., Potamogetonlucens L., Ceratophyllumdemersum L. and Chara spp. in amacrophytedominated lake. Oceanol. Hydrobiol. St. 37:51-63.

Townsend SA, Gell PA, 2005. The role of substrate type on benthic diatom assemblages in the Daly and Roper Rivers of the Australian wet/drytropics. Hydrobiologia 548:101-115.
Tunca H, Sevindik TO, Bal DN, Arabaci S, 2014. Community structure of epiphytic algae on three different macrophytes at Acarlar floodplain forest (northern Turkey). Chin. J. Oceanol. Limnol. 32:845-857.

van den Hoek C, Mann DG, Jahns HM, 1995. Algae. An introduction to phycology. Cambridge University Press, Cambridge: 640 pp. 